\title{
Hubungan Motivasi Kerja dengan Kinerja Pustakawan Bidang Pertanian di Lingkup Kementerian Pertanian
}

\section{The Relationship of Work Motivation and the Performance of Agricultural Librarians in the Ministry of Agriculture}

\author{
Erriani K ${ }^{1}$, Pudji Muljono ${ }^{2}$, Eko Sri Mulyani ${ }^{3}$ \\ ${ }^{1}$ Pusat Penelitian dan Pengembangan Perkebunan, Badan Litbang Pertanian, \\ ${ }^{2}$ Program Studi Komunikasi Pembangunan Pedesaan, Institut Pertanian Bogor, \\ ${ }^{3}$ Pusat Penelitian dan Pengembangan Pertanian, Badan Litbang Pertanian
}

\begin{abstract}
The performance of agricultural librarians in performing their duties is regulated in the functional position and its credit number according to the Regulation of Indonesian Ministry of Administrative and Bureaucratic Reform No. 9 of 2014. The regulation indicates the functional position of agricultural librarian to have certain scope of work, responsibility, authority, and rights to perform librarianship activities. Work motivation has a major influence on the betterment of libraries, which fundamentally comes from someone who is influenced by the environment or developed through his/her interaction with the environment through a learning process. Hence, it is important to analyze the relationships between agricultural librarian characteristics and work motivation, work motivation and librarian performance, as well as the difference between the motivation of expert and that of skilled librarians. Data collection was conducted at 30 institutions under the Ministry of Agriculture in West Java and Jakarta. Field data collection was conducted for two months from April to May 2017. Selection of research location was done in a purposive manner by considering those who already hold a functional position as an agricultural librarian, thus expected to support the research. Research findings showed that gender is correlated to the institutional policy, and level of non-formal education is correlated to institutional policy and benefits. Education is shown to be correlated to institutional polic; library management is correlated to achievement, acknowledgement, the job itself, improvement, interpersonal relationship, and salary or benefit. Meanwhile, library service is correlated to interpersonal relationship and salary or benefit. In terms of the difference in motivations of expert and skilled agricultural librarians, only the quality of supervision/superior showed any difference between expert and skilled agricultural librarians.
\end{abstract}

Keyword: Librarian, Motivation, Performance

\begin{abstract}
Abstrak
Kinerja pustakawan bidang pertanian dalam menjalankan tugasnya diatur dalam jabatan fungsional dan angka kreditnya berdasarkan Peraturan Menteri Pendayagunaan Aparatur Negara dan Reformasi Birokrasi Republik Indonesia Nomor 9 Tahun 2014. Ketentuan tersebut diharapkan jabatan fungsional pustakawan bidang pertanian mempunyai ruang lingkup tugas, tanggung jawab, wewenang, dan hak untuk melaksanakan kegiatan kepustakawanan. Motivasi kerja sangat berpengaruh besar terhadap kemajuan perpustakaan, pada dasarnya motivasi bersumber pada diri seseorang yang dipengaruhi oleh lingkungan atau berkembang melalui proses interaksinya dengan lingkungan melalui proses belajar. Sehingga perlu dianalisis hubungan karakteristik pustakawan bidang pertanian dengan motivasi kerja, hubungan motivasi kerja dengan kinerja pustakawan, serta perbedaan motivasi pustakawan ahli dan terampil. Penelitian ini dilakukan di 30 instansi Kementerian Pertanian lingkup Jawa Barat dan Jakarta. Pengumpulan data di lapangan dilaksanakan selama dua bulan terhitung dari bulan April-Mei 2017. Pemilihan lokasi penelitian dilakukan secara sengaja (purposive) dengan pertimbangan sudah menjabat fungsional pustakawan bidang pertanian, sehingga diharapkan mampu mendukung terlaksananya penelitian. Hasil penelitian menunjukkan bahwa jenis kelamin berhubungan dengan Kebijakan instansi, dan tingkat pendidikan non formal berhubungan dengan kebijakan instansi serta gaji/ tunjangan. Selanjutnya pendidikan berhubungan dengan kebijakan instansi, pengelolaan perpustakaan berhubungan dengan prestasi; pengakuan; pekerjaan itu sendiri; kemajuan; hubungan interpersonal; gaji/tunjangan. Serta pelayanan perpustakaan berhubungan dengan hubungan interpersonal dan gaji/tunjangan. Dilihat dari perbedaan motivasi pustakawan bidang pertanian ahli dan terampil, hanya kualitas supervisi/atasan yang memiliki perbedaan antara pustakawan bidang pertanian ahli dan terampil.
\end{abstract}

Kata kunci: Kinerja, Motivasi, Pustakawan

\section{Pendahuluan}

Pustakawan bidang pertanian dituntut lebih profesionalkarena semakinmajunyailmupengetahuan dan teknologi informasi diharapkan pustakawan bidang pertanian mampu menempatkan berbagai 
peluang dalam menghadapi tantangan. Menurut Gatot (2009), upaya pengembangan pengetahuan diperlukan kemampuan pustakawan yang profesional dalam hal mengemban tugas dan tanggung jawabnya di bidang perpustakaan yang disertai pengembangan diri individu pustakawan. Pustakawan yang berdedikasi tinggi adalah pustakawan yang semangat memikirkan kemajuan perpustakaan untuk instansinya tanpa harus menunggu perintah dari atasannya. Segala sesuatu yang dianggap masih kurang dalam instansinya akan dicarikan solusi secara cepat dan tepat. Prestasi pustakawan dapat ditunjukkan oleh kinerja dan kontribusi pustakawan dalam mengembangkan layanan di perpustakaan, (Wahid dan Dwi, 2015). Kinerja pustakawan menurut Erni (2015) mengatakan bahwa prestasi kerja yang dicapai oleh seseorang atau kelompok orang dalam melaksanakan suatu tugas yang harus diemban oleh pustakawan dalam upaya mencapai tujuan perpustakaan. Definisi kinerja menurut Robbins (2002) menyatakan bahwa konsep kinerja bersifat universal, efektivitas operasional suatu organisasi berdasarkan standar dan kriteria yang sudah ditetapkan oleh organisasi pada dasarnya dijalankan oleh manusia, maka kinerja sesungguhnya merupakan perilaku manusia dalam suatu organisasi untuk memenuhi standar perilaku yang telah ditetapkan untuk membuahkan tindakan dan hasilyang diinginkan. Mangkunegara (2014) mengemukakan bahwa kinerja adalah hasil kerja secara kualitas dan kuantitas yang dicapai oleh seorang pegawai dalam melaksanakan tugasnya sesuai dengan tanggung jawab yang diberikan. Sedangkan menurut Wirawan (2009) kinerja adalah keluaran yang dihasilkan oleh fungsi-fungsi dan indikator-indikator suatu pekerjaan atau suatu profesi dalam waktu tertentu.

Kinerja pustakawan dalam menjalankan tugasnya diatur dalam jabatan fungsional dan angka kreditnya berdasarkan Peraturan Menteri Pendayagunaan Aparatur Negara dan Reformasi Birokrasi Republik Indonesia Nomor 9 Tahun 2014. Peraturan tersebut diharapkan jabatan fungsional pustakawan mempunyai ruang lingkup tugas, tanggung jawab, wewenang, dan hak untuk melaksanakan kegiatan kepustakawanan. Peningkatan kualitas kinerja pustakawan terdapat dalam Undang-Undang Republik Indonesia Nomor 43 Tahun 1999 yang mengamanatkan tentang pokokpokok kepegawaian, berdasarkan sistem karier dan prestasi kerja memberikan penghargaan dan sanksi. Penghargaan yang ditujukan kepada pustakawan adalah untuk membangun semangat pustakawan untuk lebih profesional dan lebih mampu serta akuntabel dalam memberikan pelayanan kepada publik dalam menjalankan semua tugasnya. Adapun sanksi yang dicantumkan dalam undang-undang tersebut, apabila pustakawan tidak menjalankan tugasnya dengan baik tujuannya agar pustakawan lebih disiplin dikarenakan tugas pustakawan sangat penting untuk menjaga semua koleksi perpustakaan berupa buku, dokumen rahasia ataupun berbentuk digital. Pustakawan selaku Pegawai Negeri Sipil (PNS) yang menyandang jabatan fungsional di harapkan mampu mewujudkan kinerja yang profesional dan berkualitas.

Profesi pustakawan bidang pertanian sebagian besar aktivitasnya berhadapan langsung dan berkomunikasi dengan orang lain. Pustakawan dituntut untuk mampu berkomunikasi interpersonal dengan baik dan efektif, karena sebagai seorang profesional yang bertanggungjawab untuk menyediakan akses yang seluas-luasnya untuk para pencari informasi, yang dikemukakan dari hasil penelitian (Makarim 2006). Motivasi cenderung merupakan karakteristik spikologi manusia yang akan muncul dan meningkatkan semangat kerja karyawan. Motivasi dinilai penting untuk efektivitas suatu organisasi. Menurut Stoner (2002) motivasi merupakan prediktor dari kinerja karyawannya. Motivasi sangat penting untuk dimiliki dari seorang pustakawan yang akan berhubungan dengan kinerja mereka. Berdasarkan penelitian Rachmawati (2013) bahwa motivasi kerja yang dimiliki oleh setiap karyawan merupakan salah satu hal yang sangat berpengaruh dalam meningkatkan kinerja karyawan, sehingga banyak institusi maupun perusahaan meningkatkan motivasi kerja karyawan.

Keberadaan pustakawan bidang pertanian sangat berpengaruh besar terhadap kemajuan perpustakaan, oleh karenanya sumber daya manusia yang handal sangat diperlukan untuk mencapai tujuan yang direncanakan oleh perpustakaan. Hasibuan (2012) menyatakan bahwa motivasi mempersoalkan bagaimana mengarahkan daya dan potensi kepada bawahan untuk bekerjasama secara produktif untuk mencapai keberhasilan sehingga terwujudnya tujuan. Suwatno dan Donni (2011) mendefinisikan motivasi kerja sebagai kesediaan untuk melaksanakan upaya tinggi untuk mencapai tujuan-tujuan keorganisasian yang dikondisikan oleh kemampuan upaya untuk memenuhi kebutuhan individual tertentu. Danim (2004) mengungkapkan bahwa motivasi adalah setiap kekuatan yang muncul dari dalam diri individu untuk mencapai tujuan atau keuntungan 
tertentu di lingkungan dunia kerja atau di pelataran kehidupan pada umumnya. Chung dan Meggison dalam Irham (2016) menyatakan bahwa motivasi dirumuskan sebagai perilaku yang ditujukan pada sasaran, motivasi berkaitan dengan tingkat usaha yang dilakukan oleh seseorang untuk mengejar suatu tujuan motivasi berkaitan erat dengan kepuasan dan performansi pekerjaan. Serta menurut Marihot (2009) mendifinisikan motivasi adalah faktor-faktor yang mengarahkan dan mendorong perilaku atau keinginan seseorang untuk melakukan suatu kegiatan yang dinyatakan dalam bentuk usaha yang keras atau lemah.

Tujuan motivasi menurut Hasibuan (2012) yakni: (1) meningkatkan moral dan kepuasan kerja; (2) meningkatkan produktivitas karyawan; (3) mempertahankan kestabilan karyawan perusahaan; (4) meningkatkan kedisiplinan karyawan; (5) mengefektifkan pengadaan karyawan; (6) menciptakan suasana dan hubungan kerja yang baik; (7) meningkatkan loyalitas, kreativitas, dan partisipasi karyawan; (8) meningkatkan tingkat kesejahteraan karyawan; (9) mempertinggi rasa tanggung jawab karyawan terhadap tugas-tugasnya; (10) meningkatkan efisiensi penggunaan alat-alat dan bahan baku. Hasibuan (2012) memaparkan ada dua jenis motivasi, yaitu: (1) motivasi positif, maksudnya manajer memotivasi (merangsang) bawahan dengan memberikan hadiah kepada mereka yang berprestasi di atas prestasi standar. Dengan motivasi positif, semangat kerja bawahan akan meningkat karena umumnya manusia senang menerima yang baikbaik saja; (2) motivasi negatif, maksudnya manajer memotivasi bawahan dengan standar mereka akan mendapat hukuman. Dengan motivasi negatif ini semangat bekerja bawahan dalam jangka waktu pendek akan meningkat karena mereka takut dihukum, tetapi untuk jangka waktu panjang dapat berakibat kurang baik.

Sidanti (2015) mengungkapkan bahwa motivasi adalah suatu model dalam menggerakkan dan mengarahkan para karyawan agar dapat melaksanakan tugasnya masing-masing dalam mencapai sasaran dengan penuh kesadaran, kegairahan dan bertanggung jawab. Penelitian Parmiti (2006) menyatakan tentang motivasi kerja, bahwa terjadinya hubungan positif signifikan antara motivasi kerja dengan kinerja pustakawan, semakin tinggi motivasi kerja pustakawan maka akan semakin tinggi pula kinerja pustakawan. Penelitian Brahmasari et al. (2008) mengatakan bahwa motivasi kerja berpengaruh positif namun tidak signifikan terhadap kinerja perusahaan, motivasi kerja berpengaruh positif dan signifikan terhadap kepuasan kerja tetapi belum tentu mempengaruhi kinerja perusahaan, dalam hal ini bisa terjadi apabila karyawan merasa sejahtera sudah terpenuhi kebutuhannya oleh pihak manajemen sehingga dapat bekerja secara maksimal. Penelitian menurut Sumbangsih dan Nelisa (2013) berdasarkan hasil wawancara bahwa pustakawan dan karyawan termotivasi untuk bekerja dikarenakan sudah memenuhi untuk kebutuhan hidupnya, disamping itu mereka termotivasi bekerja karena untuk mencari pengalaman untuk mengaplikasikan ilmunya sewaktu masih di dunia pendidikan sebelum mereka bekerja.

Penelitian menurut Sudarto dan Lubis (2009), Bachtiar (2012), Riyadi (2011), Jaya (2012), dan Mamik (2010) berdasarkan hasil estimasi yang diperoleh menyatakan bahwa motivasi memberikan pengaruh yang signifikan terhadap kinerja di perusahaan, motivasi yang ada dalam perusahaan tersebut sudah memadai maka mampu mendorong peningkatan kinerja karyawan. Lima hasil penelitian tersebut sesuai dengan Goal Theory (Suprihanto 1987) yang menjelaskan bahwa kinerja atau prestasi seseorang tergantung pada motivasi orang tersebut terhadap pekerjaan yang dilakukan, semakin tinggi motivasi seseorang dalam melakukan pekerjaan semakin tinggi pula tingkat kinerjanya, sebaliknya semakin rendah motivasi seseorang melakukan suatu pekerjaan maka semakin rendah pula tingkat kinerjanya. Hasil ini juga sejalan dengan pendapat Robbins (1998) dan Mitchell (1998). Sumbangsih dan Nelisa (2013) menyatakan bahwa penyebab utama kurangnya semangat kerja pustakawan yaitu faktor kebutuhan, karena tujuan utama seseorang untuk bekerja adalah memenuhi kebutuhan hidupnya.

Motivasi sangat penting pada diri pustakawan bidang pertanian, motivasi kerja dan kinerja pustakawan diharapkan akan saling berhubungan satu sama lain sehingga motivasi kerja dan kinerja pustakawan perlu untuk dilihat bagaimana hubungannya. Pada penelitian ini kinerja pustakawan dibagi menjadi dua penilaian yaitu berdasarkan penilaian angka kredit jabatan fungsional dan penilaian perilaku kerja.

Berdasarkan uraian tersebut maka penelitian ini memiliki tujuan untuk menganalisis hubungan antara karakteristik pustakawan dengan motivasi kerja, menganalisis hubungan motivasi kerja dengan kinerja pustakawan, serta melihat bagaimana 
perbedaan motivasi kerja antara pustakawan bidang pertanian ahli dan terampil.

\section{Metode Penelitian}

Lokasi penelitian dilaksanakan di 30 instansi Kementerian Pertanian lingkup Jawa Barat dan Jakarta. Pengumpulan data di lapangan dilaksanakan selama dua bulan terhitung dari bulan April-Mei 2017. Pemilihan lokasi penelitian dilakukan secara sengaja (purposive) dengan pertimbangan sudah menjabat fungsional pustakawan, sehingga diharapkan mampu mendukung terlaksananya penelitian. Data yang dikumpulkan dalam penelitian ini terdiri dari data primer dan data sekunder. Data primer merupakan data yang diperoleh secara langsung dari responden, data primer dalam penelitian ini yakni: karakteristik pustakawan bidang pertanian, kompetensi komunikasi interpersonal, kemampuan mencari informasi, motivasi kerja, dan kinerja pustakawan bidang pertanian, yang didapat dengan menggunakan instrumen kuesioner. Data sekunder yang diperoleh dalam penelitian ini antara lain data pustakawan lingkup Kementerian Pertanian tahun 2016, tugas dan fungsi pokok pejabat fungsional pustakawan bidang pertanian terampil dan fungsional pustakawan ahli. Teknik analisis yang digunakan ialah statitik deskriptif dan statistik inferensial.

Populasi merupakan jumlah keseluruhan dari unit-unit analisis yang memiliki ciri-ciri yang diduga. Populasi pada penelitian ini adalah seluruh pustakawan lingkup Kementerian Pertanian, pustakawan bidang pertanian yang sudah menjabat fungsional. Jumlah responden dalam penelitian ini adalah sebanyak 72 orang. Data pendukung penelitian dibutuhkan sejumlah informasi dari informan yaitu atasan langsung pustakawan untuk memberikan informasi mengenai kinerja pustakawan bidang pertanian, Tim Penilai Jabatan Pustakawan bidang pertanian (TPJP) sehingga akan terwakili tentang penilaian kinerja pustakawan.

Data yang diperoleh dari kuesioner dikelompokkan berdasarkan variabel yang sudah ditentukan lalu ditabulasi. Data diolah dan dianalisis sesuai kebutuhan untuk menjawab rumusan masalah dan tujuan penelitian untuk menguji hipotesis penelitian. Teknik pengolahan data menggunakan analisis kuantitatif dan data kualitatif digunakan untuk mendukung atau mempertajam analisis kuantitatif. Data yang diperoleh pada penelitian diakumulasikan dan disusun secara sistematis untuk kemudian dianalisis dengan menggunakan teknikteknik analisis deskriptif dan analisis inferensial.

Analisis statistik inferensial yang digunakan adalah analisis korelasi Rank Spearman (rs) yang menguji hipotesis mengenai hubungan peubah bebas dengan peubah terikat (Kriyantono 2010). Menguji hipotesis korelasi bila datanya berbentuk ordinal, rumus Korelasi Rank Spearman (Silalahi 2010):

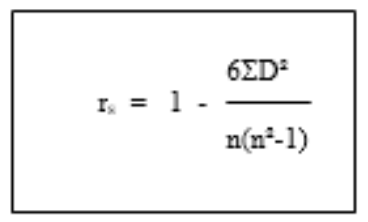

Keterangan:

rs (rho) = Koefisien korelasi rank-order

D2 = Perkalian perbedaan pasangan antara dua set nilai yang telah diurutkan

$\mathrm{n} \quad=$ Jumlah kasus atau sampel yang diurut

Sementara untuk menganalisis perbedaan pustakawan bidang pertanian terampil dan pustakawan ahli dilakukan dengan menggunakan uji beda dengan menggunakan rumus sebagai berikut (Kriyantono, 2009):

$\mathrm{t}=\frac{\mathrm{x} 1-\mathrm{x} 2}{S(\mathrm{x} 1-\mathrm{x} 2)}$

Keterangan:

$\mathrm{t}=$ Nilai statistik ( $\mathrm{r}$ hitung)

x1 = Rata-rata skor dari pustakawan terampil

x2 = Rata-rata skor dari pustakawan ahli

$\mathrm{S}=$ Standar error kedua jenjang pustakawan

Motivasi kerja adalah kesediaan untuk melaksanakan upaya tinggi untuk mencapai tujuantujuan keorganisasian yang dikondisikan oleh kemampuan upaya untuk memenuhi kebutuhan individual tertentu, yang diukur berdasarkan indikator, meliputi: (1) Kondisi (motivasi), meliputi: a. Prestasi, b. Pengakuan, c. Pekerjaan itu sendiri, d. Tanggung jawab, e. kemajuan. Rangkaian ini melukiskan hubungan seseorang dengan apa yang dikerjakannya (job-content) yakni kandungan kerja pada tugasnya. (2) Kondisi ekstrinsik (higienis), meliputi: a. Kebijaksanaan Perusahaan, b. Kualitas Supervisi, c. Hubungan interpersonal, d. Kondisi 
Kerja, e. Gaji dan tunjangan.

\section{Hasil dan Pembahasan}

\section{Karakteristik Pustakawan Bidang Pertanian}

Usia responden penelitian berkisar 29 tahun sampai dengan usia 60 tahun. Pengkatagorian usia responden mengacu kepada PP no. 21 Tahun 2014 Peraturan Pemerintah Republik Indonesia pemberhentian Pegawai Negeri Sipil yang mencapai batas usia pensiun bagi pejabat fungsional pada usia 65 (enam puluh lima) tahun yang memangku sampai dengan Jabatan Fungsional Pustakawan Utama. Pustakawan bidang pertanian ahli mayoritas di dominasi oleh pustakawan bidang pertanian berjenis kelamin perempuan dengan jumlah orang sebanyak 30 orang atau sebesar 71 persen. Sementara pustakawan bidang pertanian laki-laki ahli yaitu sebanyak 12 orang atau sebesar $29 \%$ dari total pustakawan bidang pertanian ahli. Pustakawan bidang pertanian terampil memiliki kondisi yang berlawanan arah terhadap pustakawan ahli.

Mayoritas pustakawan bidang pertanian terampil berjenis kelamin laki-laki dengan persentase sebesar $57 \%$ atau sebanyak 17 orang. Sedangkan pustakawan bidang pertanian terampil berjenis kelamin laki-laki berjumlah 13 orang dengan persentase sebesar $43 \%$. Pada penelitian ini tingkat pendidikan diklasifikasikan menjadi empat yaitu SMA, Diploma, Sarjana, dan Pascasarjana. Berdasarkan Tabel 9 menunjukkan bahwa dari jumlah responden sebanyak 72 orang pustakawan lingkup Kementerian Pertanian wilayah Jabar dan Jakarta sebagian besar sudah berpendidikan Sarjana yaitu sebanyak 31 orang (74\%) kemudian 25 orang (83\%) adalah Diploma. Masih adanya pustakawan bidang pertanian yang berpendidikan SMA sebanyak 5 orang (17\%) dikarenakan pada peraturan fungsional yang lama untuk menjabat fungsional pustakawan

Tabel 1. Jumlah dan Presentase Responden berdasarkan Katagori Karakteristik Pustakawan Bidang Pertanian

\begin{tabular}{|c|c|c|c|c|}
\hline \multirow{2}{*}{$\begin{array}{l}\text { Karakteristik pustakawan } \\
\text { bidang pertanian }\end{array}$} & \multicolumn{2}{|c|}{ Jumlah (orang) } & \multicolumn{2}{|c|}{ Persentase $(\%)$} \\
\hline & Ahli & Terampil & Ahli & Terampil \\
\hline \multicolumn{5}{|l|}{ Usia } \\
\hline$<35$ tahun (muda) & 7 & 4 & 16,67 & 13,33 \\
\hline 35-49 tahun (sedang) & 15 & 5 & 35,71 & 16,67 \\
\hline 50-65 tahun (tua) & 20 & 21 & 47,62 & 70,00 \\
\hline \multicolumn{5}{|l|}{ Jenis Kelamin } \\
\hline Laki-laki & 12 & 17 & 28,57 & 56,67 \\
\hline Perempuan & 30 & 13 & 71,43 & 43,33 \\
\hline \multicolumn{5}{|l|}{ Tingkat pendidikan formal } \\
\hline SMA & 0 & 5 & 0,00 & 16,67 \\
\hline DIPLOMA & 0 & 25 & 0,00 & 83,33 \\
\hline SARJANA & 31 & 0 & 73,81 & 0,00 \\
\hline PASCASARJANA & 11 & 0 & 26,19 & 0,00 \\
\hline \multicolumn{5}{|l|}{ Tingkat pendidikan non formal } \\
\hline 1 - 16 jam (rendah) & 4 & 3 & 9.52 & 10.00 \\
\hline $17-24$ jam (sedang) & 16 & 21 & 38,10 & 70,00 \\
\hline$>24$ jam (tinggi) & 22 & 6 & 52,38 & 20,00 \\
\hline \multicolumn{5}{|l|}{ Masa kerja fungsional } \\
\hline 1-10 tahun (singkat) & 29 & 11 & 69.05 & 36.67 \\
\hline 10-20 tahun (sedang) & 6 & 12 & 14.29 & 40.00 \\
\hline$>20$ tahun (tinggi) & 7 & 7 & 16.66 & 23.33 \\
\hline
\end{tabular}


minimal berpendidikan SMA atau sederajat.

Tingkat pendidikan non formal pada pustakawan bidang pertanian terampil berdasarkan hasil penelitian tertinggi 38\% pada katagori sedang rata-rata 17- 24 jam mengikuti pendidikan non formal selama kurang lebih satu tahun, sementara pada katagori tinggi sebanyak $20 \%$ dengan ratarata $>24$ jam dan katagori rendah berkisar $10 \%$ dengan rata-rata 1-16 jam per tahunnya. Pustakawan bidang pertanian terampil dalam katagori rendah dikarenakan baru masuknya ke jenjang fungsional pustakawan sehingga masih sedikitnya mengikuti pendidikan non formal. Masa kerja fungsional dibagi atas tiga kategori yaitu masa kerja yang singkat, sedang serta tinggi. Pustakawan bidang pertanian ahli memiliki masa kerja fungsional yang mayoritas singkat berkisar 1-10 tahun atau sebesar 69\%. Masa kerja fungsional terampil pada kategori sedang sebesar 14\% dengan masa kerja selama 10 hingga 20 tahun. Sedangkan pustakawan ahli berkategori tinggi memiliki masa jabatan yang lama lebih dari 20 tahun memiliki persentase sebesar $17 \%$.

\section{Deskripsi Motivasi Kerja}

Herzberg (1966) menemukan bahwa agar karyawan termotivasi, mereka harus merasa secara pribadi bertanggung jawab atas pekerjaan dan akan membuat mereka bekerja lebih keras mencapai tujuan pribadi mereka sendiri, serta tujuan organisasi. Menurut Inyang et al.,(2014) dalam penelitiannya terhadap pustakawan yang menyatakan bahwa menganalisis motivasi sangat dibutuhkan agar perpustakaan dapat menyesuaikan motivasi pustakawan dengan hal yang mereka harapkan.

Tabel 2 mayoritas pustakawan ahli dan terampil setuju bahwa kondisi supervisi/atasan dapat memenuhi motivasi kerja pustakawan di lingkungan kementerian pertanian. Prestasi merupakan penilaian karyawan terhadap baiknya pekerjaan yang mereka lakukan dan penyelesaian pekerjaan yang tepat waktu. Mayoritas pustakawan ahli dan terampil setuju bahwa mereka dapat menyelesaikan pekerjaannya dengan baik dan menyelesaikan tugas tepat waktu sesuai dengan target yang ditentukan dengan persentase berturut-turut $88.10 \%$ dan $73.33 \%$. Prestasi kerja erat kaitannya dengat penyelesaian target-target kerja bagi masing-masing responden. Motivasi kerja sangat berpengaruh terhadap munculnya prestasi kerja karyawan, seperti yang dilansir dari penelitian Yatipala et al.,(2015) yang menyatakan bahwa motivasi kerja merupakan satu-satunya supervisi yang dapat meningkatkaan prestasi kerja karyawan.

Tabel 3 pada indikator ekstrinsik dapat memotivasi seseorang untuk keluar dari ketidakpuasan yang meliputi kebijakan instansi, kualitas atasan, hubungan interpersonal, kondisi kerja dan gaji tunjangan. Kebijakan instansi tempat bekerja dalam hal ini perpustakaan dilingkup Kementerian Pertanian merupakan penilaian pustakawan bidang pertanian terhadap kebijakan instansinya tersebut. Kebijakan instansi lingkup Kementerian Pertanian diatur oleh arahan dan pengembangan pustakawan Kementerian

Tabel 2. Jumlah dan Persentase Responden terhadap Motivasi Kerja

\begin{tabular}{|c|c|c|c|c|c|c|c|}
\hline \multirow{3}{*}{ Motivasi } & \multirow{3}{*}{ Kelompok } & \multicolumn{6}{|c|}{ Jumlah dan Persentase responden } \\
\hline & & \multicolumn{2}{|c|}{ Sangat setuju } & \multicolumn{2}{|c|}{ Setuju } & \multicolumn{2}{|c|}{ Tidak setuju } \\
\hline & & (org) & $(\%)$ & (org) & $(\%)$ & (org) & $(\%)$ \\
\hline \multicolumn{8}{|l|}{ Intrinsik } \\
\hline \multirow{2}{*}{ Prestasi } & Ahli & 5 & 11,90 & 37 & 88,10 & 0 & 0,00 \\
\hline & Terampil & 8 & 26,67 & 22 & 73,33 & 0 & 0,00 \\
\hline \multirow{2}{*}{ Pengakuan } & Ahli & 9 & 21,43 & 33 & 78,57 & 0 & 0,00 \\
\hline & Terampil & 13 & 43,33 & 17 & 56,67 & 0 & 0,00 \\
\hline \multirow{2}{*}{ Pekerjaan itu sendiri } & Ahli & 15 & 35,71 & 27 & 64,29 & 0 & 0,00 \\
\hline & Terampil & 15 & 50,00 & 15 & 50,00 & 0 & 0,00 \\
\hline \multirow{2}{*}{ Taggung Jawab } & Ahli & 9 & 21,43 & 31 & 73,81 & 2 & 4,76 \\
\hline & Terampil & 9 & 30,00 & 21 & 70,00 & 0 & 0,00 \\
\hline \multirow{2}{*}{ Kemajuan } & Ahli & 10 & 23,81 & 32 & 76,19 & 0 & 0,00 \\
\hline & Terampil & 13 & 43,33 & 17 & 56,67 & 0 & 0,00 \\
\hline
\end{tabular}


Tabel 3. Jumlah dan Persentase Responden terhadap Motivasi Kerja

\begin{tabular}{|c|c|c|c|c|c|c|c|}
\hline \multirow{3}{*}{ Motivasi } & \multirow{3}{*}{ Kelompok } & \multicolumn{6}{|c|}{ Jumlah dan Persentase responden } \\
\hline & & \multicolumn{2}{|c|}{ Sangat setuju } & \multicolumn{2}{|c|}{ Setuju } & \multicolumn{2}{|c|}{ Tidak setuju } \\
\hline & & (org) & $(\%)$ & (org) & $(\%)$ & (org) & $(\%)$ \\
\hline \multicolumn{8}{|l|}{ Ekstrinsik } \\
\hline \multirow{2}{*}{ Kebijakan instansi } & Ahli & 10 & 23,81 & 32 & 76,19 & 0 & 0,00 \\
\hline & Terampil & 14 & 46,67 & 16 & 53,33 & 0 & 0,00 \\
\hline \multirow{2}{*}{ Kualitas supervisi/atasan } & Ahli & 9 & 21.43 & 33 & 78,57 & 0 & 0,00 \\
\hline & Terampil & 9 & 30,00 & 21 & 70,00 & 0 & 0,00 \\
\hline \multirow{2}{*}{ Hubungan interpersonal } & Ahli & 14 & 33,33 & 28 & 66,67 & 0 & 0,00 \\
\hline & Terampil & 14 & 46,67 & 16 & 53,33 & 0 & 0,00 \\
\hline \multirow{2}{*}{ Kondisi kerja } & Ahli & 17 & 40,48 & 25 & 59,52 & 0 & 0,00 \\
\hline & Terampil & 17 & 56,67 & 13 & 43,33 & 0 & 0,00 \\
\hline \multirow{2}{*}{ Gaji Tunjangan } & Ahli & 4 & 9,52 & 29 & 69,05 & 9 & 21,43 \\
\hline & Terampil & 3 & 10,00 & 20 & 66,67 & 7 & 23,33 \\
\hline
\end{tabular}

Pertanian sesuai dengan UU ASN no.5 Tahun 2004. Pustakawan bidang pertanian ahli sebesar $76.19 \%$ dan pustakawan bidang pertanian terampil sebesar $53.33 \%$ setuju bahwa kebijakan instansi dan peraturan yang ada pada instansinya setuju untuk ditaati. Hal ini berbeda dengan penelitian yang dilakukan oleh Senyah (2003) yang menemukan bahwa menyesuaikan kebijakan instansi bagi pustakawan hanya direspon sekitar 5,9\% dari pustakawan. Hal ini menunjukkan bahwa budaya kerja dan manajemen kebijakan masing-masing instansi akan sangat menentukan motivasi kerja pustakawannya.

\section{Hubungan Karakteristik dengan Motivasi Kerja}

Motivasi mempersoalkan bagaimana cara mengarahkan daya dan potensi bawahan agar mau bekerja sama secara produktif berhasil mencapai dan mewujudkan tujuan yang telah ditentukan Mangkunegara (2014). Indikator tersebut dilansir dari teori motivasi dan higienis Herzberg, (1966) yang meliputi: (1) Kondisi intrinsik (faktor motivasi), meliputi: a. Prestasi, b. Pengakuan, c. Pekerjaan itu sendiri, d. Tanggung jawab, e. Kemajuan. Rangkaian ini melukiskan hubungan seseorang dengan apa yang dikerjakannya (job-content) yakni kandungan kerja pada tugasnya. (2) Kondisi ekstrinsik (faktor higienis), meliputi: a. Kebijaksanaan Perusahaan, b. Kualitas Supervisi, c. Hubungan interpersonal, d. Kondisi Kerja, e. Gaji dan tunjangan.

Berdasarkan pada Tabel 4 hasil analisis rank spearman pada faktor intrinsik tidak terdapat hubungan nyata antara karakteristik pustakawan bidang pertanian terhadap prestasi, pengakuan, pekerjaan itu sendiri, tanggung jawab dan kemanjuan. Hal ini mengindikasikan bahwa setiap responden dengan karakteristik masing-masing tidak dapat dihubungkan dengan motivasi mereka dalam hal menjalankan pekerjaan dengan sebaik mungkin, menetapkan target pekerjaan dalam waktu

Tabel 4. Hubungan antara Karakteristik Pustakawan Bidang Pertanian dan Motivasi Kerja

\begin{tabular}{|c|c|c|c|c|c|}
\hline \multirow{2}{*}{$\begin{array}{c}\text { Karakteristik pustakawan bidang } \\
\text { pertanian }\end{array}$} & \multicolumn{5}{|c|}{ Motivasi faktor Intrinsik } \\
\hline & Prestasi & Pengakuan & $\begin{array}{l}\text { Pekerjaan } \\
\text { itu sendiri }\end{array}$ & $\begin{array}{c}\text { Taggung } \\
\text { Jawab }\end{array}$ & Kemajuan \\
\hline Usia & .019 & .022 & .076 & .093 & .005 \\
\hline Jenis Kelamin & -.019 & -.131 & .062 & -.008 & -.119 \\
\hline Masa Kerja fungsional & .031 & -.034 & .077 & -.039 & .016 \\
\hline Tingkat Pendidikan formal & -.081 & -.180 & -.087 & -.026 & -.066 \\
\hline Tingkat Pendidikan non formal & -.212 & -.189 & -.103 & -.145 & -.188 \\
\hline
\end{tabular}

Keterangan : *Signifikan pada taraf 0.05 
Tabel 5. Hubungan antara Karakteristik Pustakawan Bidang Pertanian dan Motivasi Ekstrinsik

\begin{tabular}{lccccc}
\hline \multirow{2}{*}{ Karakteristik } & \multicolumn{5}{c}{ Motivasi faktor Ekstrinsik } \\
\cline { 2 - 6 } & $\begin{array}{c}\text { Kebijakan } \\
\text { perusahaan }\end{array}$ & $\begin{array}{c}\text { Kualitas } \\
\text { upervise/ } \\
\text { atasan }\end{array}$ & $\begin{array}{c}\text { Hubungan } \\
\text { interpersonal }\end{array}$ & $\begin{array}{c}\text { Kondisi } \\
\text { kerja }\end{array}$ & $\begin{array}{c}\text { Gaji } \\
\text { Tunjangan }\end{array}$ \\
\hline Usia & -.095 & .081 & .028 & .125 & .072 \\
Jenis Kelamin & $-.248^{*}$ & -.107 & -.042 & -.074 & -.106 \\
Masa Kerja fungsional & .005 & -.099 & .006 & .101 & -.009 \\
$\begin{array}{l}\text { Tingkat Pendidikan } \\
\text { formal }\end{array}$ & -.178 & -.072 & -.066 & -.125 & .186 \\
$\begin{array}{l}\text { Tingkat Pendidikan } \\
\text { non formal }\end{array}$ & $-.263^{*}$ & .081 & -.123 & -.065 & $.242 *$ \\
\hline
\end{tabular}

Keterangan : *Signifikan pada taraf 0.05

yang sudah ditentukan, mendapatkan penghargaan atasan, mendapatkan pengakuan dari teman sejawat, kepercayaan menyelesaikan tugas, kebebasan menyelesaikan tugas, rasa memiliki akan tugas, dan kesempatan dari atasan.

Berbeda dengan faktor intrinsik, pada Tabel 5 faktor ekstrinsik atau faktor motivasi yang berasal dari luar diri responden memiliki beberapa hubungan dari indikator-indikatornya. Berdasarkan Tabel 5, dapat dilihat bahwa jenis kelamin berhubungan nyata dengan kebijakan instansi dengan koefisien rank spearman sebesar 0,248. Tingkat pendidikan non formal berhubungan nyata dengan kebijakan instansi dengan koefisien rank Spearman sebesar 0,263. Tingkat pendidikan non formal berhubungan nyata dengan gaji dan tunjangan dengan koefisien rank Spearman sebesar 0,242.

\section{Hubungan Motivasi Kerja dengan Kinerja Pustakawan}

1. Hubungan Motivasi terhadap Kinerja Karyawan Berdasarkan PenilaianAngka Kredit Jabatan Fungsional

Berdasarkan hasil analisis korelasi menggunakan koefisien rank Spearman pada Tabel 6, ditemukan bahwa indikator prestasi berhubungan signifikan dengan pengelolaan perpustakaan dan koefisien rank Spearman sebesar 0.312. Pengakuan berhubungan signifikan pengelolaan perpustakaan yang memiliki koefisien rank Spearman sebesar 0,315 . Selanjutnya indikator pekerjaan itu sendiri berhubungan signifikan dengan pengelolaan perpustakaan dan koefisien rank Spearman sebesar 0,330. Indikator tanggung jawab tidak memiliki hubungan signifikan dengan penilaian angka kredit jabatan. Kebijakan instansi berhubungan signifikan pendidikan yang memiliki koefisien rank Spearman 0,481. Hubungan interpersonal berhubungan signifikan dengan pengelolaan perpustakaan dan pelayanan perpustakaan dengan koefisien korelasi sebesar 0,250 dan 0,260. Indikator terakhir yaitu gaji dan tunjangan hanya berhubungan signifikan dengan pengelolaan perpustakaan, pelayanan, dan pengembangan profesi dengan nilai korelasi rank spearman berturut-turut sebesar 0,766, -307, dan 0,357 .

Intrinsik Prestasi kerja seperti yang dilansir oleh Mangkunegara (2014) merupakan hasil kerja secara keseluruhan kualitas dan kuantitas yang dicapai oleh seorang karyawan dalam melaksanakan tugasnya sesuai tanggung jawab yang diberikan oleh atasannya. Prestasi kerja pada pustakawan sangat berarti untuk memotivasi mereka dalam melakukan pekerjaan. Prestasi kerja di lingkup Kementerian Pertanian diukur berdasarkan nilai yang mereka dapatkan dari pengajuan SKP yang dilihat dari awal hingga akhir tahun. Prestasi kerja berhubungan dengan pengelolaan perpustakaan. Pustakawan bidang pertanian akan merasa termotivasi bila mereka mendapatkan prestasi kerja selama satu tahunnya dan akan semakin termotivasi bila tahun berikutnya berlanjut. Dilansir dari penelitian Hermawati (2012) menyatakan bahwa motivasi dan kemampuan secara simultan berpengaruh terhadap prestasi kerja pegawai. Dengan demikian motivasi kerja tersebut akan tercermin dari bagaimana pustakawan melakukan pelayanan terhadap pegunjung. Kondisi ini juga menunjukkan bahwa hubungan antara prestasi dengan orientasi pelayanan yang berhubungan dengan koefisien rank 
Tabel 6 Hubungan Motivasi dengan Penilaian Angka Kredit Jabatan Fungsional

\begin{tabular}{lcccccc}
\hline \multicolumn{1}{c}{ Motivasi } & Pendidikan & $\begin{array}{c}\text { Pengelolaan } \\
\text { perpustakaan }\end{array}$ & $\begin{array}{c}\text { Pelayanan } \\
\text { perpustakaan }\end{array}$ & $\begin{array}{c}\text { Pengembangan } \\
\text { sistem } \\
\text { kepustakawanan }\end{array}$ & $\begin{array}{c}\text { Pengembangan } \\
\text { profesi }\end{array}$ & $\begin{array}{c}\text { Penunjagan } \\
\text { tugas } \\
\text { pustakawan }\end{array}$ \\
\cline { 2 - 7 } Intrinsik & -.162 & $-.312^{* *}$ & .222 & .044 & -.077 & -.175 \\
$\begin{array}{l}\text { Prestasi } \\
\text { Pengakuan }\end{array}$ & -.030 & $-.315^{* *}$ & .213 & .012 & -.079 & -.033 \\
$\begin{array}{l}\text { Pekerjaan itu } \\
\text { sendiri }\end{array}$ & -.046 & $-.330^{* *}$ & .125 & -.070 & .035 & -.160 \\
$\begin{array}{l}\text { Taggung } \\
\text { Jawab }\end{array}$ & -.158 & -.151 & .179 & .033 & .213 & -.052 \\
$\begin{array}{l}\text { Kemajuan } \\
\text { Ekstrinsik }\end{array}$ & .030 & $-.239 *$ & .226 & -.056 & .031 & .023 \\
$\begin{array}{l}\text { Kebijakan } \\
\text { instansi }\end{array}$ & $-.253^{*}$ & -0.076 & 0.088258 & 0.034929 & 0.079759 & -0.12993 \\
$\begin{array}{l}\text { Kualitas } \\
\text { supervisi }\end{array}$ & -.039 & -.222 & .214 & .036 & .039 & -.125 \\
$\begin{array}{l}\text { Hubungan } \\
\text { interpersonal }\end{array}$ & -.022 & $-.250^{*}$ & $.260 *$ & .001 & .003 & -.057 \\
$\begin{array}{l}\text { Kondisi kerja } \\
\text { Gaji } \\
\text { Tunjangan }\end{array}$ & -.170 & -.197 & .118 & .014 & .001 & -.130 \\
\hline
\end{tabular}

Keterangan : *Signifikan pada taraf $0.05 * *$ Signifikan pada taraf 0.05

Spearman sebesar 0,481. Artinya bahwa sikap dan perilaku kerja Pustakawan bidang pertanian dalam memberikan pelayanan terbaik kepada yang dilayani tercermin dengan tingkat prestasi mereka.

Pengakuan memiliki hubungan dengan pengelolaan perpustakaan dengan nilai koefisien rank Spearman sebesar -0,315. Pustakawan bidang pertanian ahli dan pustakawan bidang pertanian terampil setuju bahwa mereka senang bila atasan dan teman (kolega) mengakui atau menghargai prestasi pekerjaan yang mereka lakukan. Kondisi tersebut dapat meningkatkan semangat terus berprestasi pada diri pustakawan. Begitu pula dengan pekerjaan yang pustakawan lakukan di lingkup perpustakaan Kementerian Pertanian. Pekerjaan pengelolaan perpustakaan yang dilakukan sangat berhubungan dengan nilai koefisien rank Spearman sebesar -0,330. Motivasi dari dalam diri pustakawan bidang pertanian untuk mencintai pekerjaan itu sendiri berdampak kepada kecintaan mereka mengelola perpustakaan dan tentunya motivasi tersebut juga akan meningkatkan rasa ingin maju dari pustakawan bidang pertanian dalam mengelola perpustakaan dengan koefisien rank Spearman sebesar -0,239. Hal ini tidak sejalan dengan penelitian yang dilakukan oleh Sri (2006) yang menyatakan bahwa pengakuan terhadap suatu pekerjaan tidak menjadi dasar munculya motivasi untuk bekerja. Pekerjaan akan terus berjalan tanpa adanya pegakuan yang tinggi terhadap pekerjaan tersebut.

Berdasarkan hasil penelitian bahwa pekerjaan itu sendiri akan memiliki hubungan dengan penilaian angka kredit jabatan fungsional dengan koefisien rank Spearman sebesar 0,330. Hal ini mengindikasikan bahwa pengelolaan pustakawan bidang pertanian dinilai angka kreditnya dengan mempertimbangkan aspek pekerjaan yang dilakukan oleh pustakawan. Pekerjaan menjadi seorang pustakawan tidak lepas dengan kegiatan mengelola perpustakaan. Menurut PP RI no 11 Tahun 2005, pekerjaan yang dilakukan pustakawan bidang pertanian ialah kegiatan pengelolaan perpustakaan adalah kegiatan yang meliputi perencanaan, monitoring dan evaluasi penyelenggaraan kegiatan perpustakaan, sehingga motivasi yang timbul akibat pekerjaan itu sendiri akan memotivasi pustakawan untuk menaatinya sesuai petunjuk teknis yang berlaku mengenai jabatan fungsional pustakawan. Kegiatan tersebut dinilai oleh 
tim penilai untuk menjadi pertimbangaan penentuan angka kredit dari pustakawan bidang pertanian tersebut.

Kemajuan seorang pustakawan bidang pertanian berhubungan dengan pengelolaan pepustakaan dengan koefisien rank Spearman sebesar 0,239 . rasa ingin maju yang muncul dalam diri pustakawan bidang pertanian dicerminkan dengan pengelolaan perpustakaan yang baik bagi pustakawan bidang pertanian. Pengelolaan perpustakaan yang baik akan meningkatkan orientasi pelayanan yang prima pula.

Adanya hubungan antara kebijakan instansi dengan pendidikan dimana pustakawan bidang pertanian diposisikan jabatannya sesuai dengan tingkat pendidikannnya. Menurut peraturan kepala perpustakaan nasional nomor 11 Tahun 2015 tentang petunjuk teknis jabatan fungsional pustakawan dan angka kreditnya, pendidikan pustakawan dinilai atas dua yaitu pendidikan formal dan nonformal. Pendidikan formal di dapat setelah mereka menyelesaikan pendidikan yang diakui oleh Kementerian Pendidikan Tinggi, sementara pendidikan non formal ialah pendidikan dan pelatihan di bidang kepustakawanan. Kebijakan instansi diatur sesuai dengan juknis tersebut dan penggolongannya dilakukan berdasarkan ketepatan. Tidak berbeda dengan indikator kebijakan instansi, indikator hubungan interpersonal juga memiliki hubungan dengan pengelolaan dan pelayanan perpustakaan. Hubungan interpersonal terbentuk akibat adanya interaksi antara masing-masing pustakawan bidang pertanian dengan pengguna perpustakaan, atasan, teman sejawat, pengunjung perpustakaan di lingkup Kementerian Pertanian.

Gaji dan tunjangan yang didapatkan oleh pustakawan bidang pertanian berupa gaji pokok dan tunjangan. Pengelolaan dan pelayanan perpustakaan yang prima akan berpengaruh terhadap sistem penilaian kinerja pustakawan bidang pertanian yang outputnya nanti ialah nilai yang akan berpengaruh kepada besarnya tunjangan yang mereka terima. Sehingga sangat penting untuk melakukaan pengelolaan dan pelayanan perpustakaan yang baik. Winarni (2013) menyatakan bahwa ada pengaruh signifikan gaji terhadap motivasi kerja pegawai Kantor Perpustakaan dan Arsip Kota Salatiga,. Penelitian tersebut menunjukkan bahwa gaji mempengaruhi motivasi pustakawan bekerja di perpustakaan. Begitu pula dengan kinerja dinyatakan oleh Winarni (2013) yaitu ada pengaruh signifikan gaji terhadap kinerja pegawai Kantor Perpustakaan dan Arsip Kota Salatiga.

2. Hubungan Motivasi Kerja terhadap Kinerja Putakawan Bidang Pertanian berdasarkan Perilaku Kerja Pustakawan

Tabel 7. Hubungan Motivasi kerja terhadap Kinerja Putakawan berdasarkan Perilaku Kerja Pustakawan

Penilaian perilaku kerja

\begin{tabular}{lccccc}
\cline { 2 - 5 } \multicolumn{1}{c}{ Motivasi } & $\begin{array}{c}\text { Orientasi } \\
\text { pelayanan }\end{array}$ & Integritas & Komitmen & Kedisplinan & Kerjasama \\
\hline Intrinsik & & & & & \\
Prestasi & $.481^{* *}$ & $.475^{* *}$ & .184 & $.515^{* *}$ & $.433^{* *}$ \\
Pengakuan & $.419^{* *}$ & $.568^{* *}$ & $.546^{* *}$ & $.832^{* *}$ & $.701^{* *}$ \\
Pekerjaan itu sendiri & $.511^{* *}$ & $.303^{* *}$ & $.286^{*}$ & $.482^{* *}$ & $.386^{* *}$ \\
Taggung Jawab & $.335^{* *}$ & $.263^{*}$ & $.269^{*}$ & $.306^{* *}$ & $.294^{*}$ \\
Ekstrinsik & & & & & $.433^{* *}$ \\
Kemajuan & $.651^{* *}$ & $.413^{* *}$ & .211 & $.268^{*}$ \\
Kebijakan instansi & $.396^{* *}$ & $.832^{* *}$ & $.304^{* *}$ & $.490^{* *}$ & $.395^{* *}$ \\
Kualitas supervisi/atasan & $.240^{*}$ & $.381^{* *}$ & $1.000^{* *}$ & $.520^{* *}$ & $.363^{* *}$ \\
Hubungan interpersonal & $.540^{* *}$ & $.527^{* *}$ & $.520^{* *}$ & $1.000^{* *}$ & $.786^{* *}$ \\
Kondisi kerja & $.502^{* *}$ & $.505^{* *}$ & $.363^{* *}$ & $.786^{* *}$ & $1.000^{* *}$ \\
Gaji Tunjangan & -.006 & .047 & -.038 & -.023 & .002 \\
\hline
\end{tabular}

Keterangan : *Signifikan pada taraf $0.05 * *$ Signifikan pada taraf 0.05 
Hasil penelitian hubungan motivasi terhadap penilaian perilaku kerja di dapatkan bahwa motivasi intrinsik hampir keseluruhan memiliki hubungan dengan penilaian perilaku kerja. Akan tetapi hanya prestasi yang tidak berhubungan dengan komitmen dengan koefiien rank spearman sebesar 0,184. Begitu juga dengan faktor ektrinsik hampir keseluruhan memiliki hubungan dengan penilaian perilaku kerja. Akan tetapi kemajuan tidak berhubungan dengan komitmen dengan koefisien rank spearman sebesar 0,211 . Serta gaji dan tunjangan tidak memiliki hubungan yang signifikan dengan seluruh penilaian perilaku kerja.

Motivasi kerja tersebut akan tercermin dari bagaimana pustakawan bidang pertanian melakukan pelayanan terhadap pegunjung. Kondisi ini juga menunjukkan bahwa hubungan antara prestasi dengan orientasi pelayanan yang berhubungan dengan koefisien rank spearman sebesar 0,481. Artinya bahwa sikap dan perilaku kerja pustakawan bidang pertanian dalam memberikan pelayanan terbaik kepada yang dilayani tercermin dengan tingkat prestasi mereka. Prestasi memiliki hubungan nyata dengan integritas dari pustakawan bidang pertanian dengan koefisien rank spearman sebesar 0,475. Pustakawan bidang pertanian dengan prestasi yang baik akan memiliki kemampuan untuk bertindak sesuai dengan nilai, norma dan etika dalam institusi Kementerian Pertanian. Motivasi seorang pustakawan bidang pertanian akan menghasilakan integritas yang mampu mencapai tujuan organisasi. Sehingga ketika pustakawan bidang pertanian dengan prestasi yang baik akan menunjukkan integritas yang baik juga di dalam peforma pekerjaan mereka. Begitu pula dengan kedisiplinan dan kerja sama yang memiliki hubungan dengan prestasi dengan koefisien rank spearman sebesar 0,515 dan 0,433. kondisi ini mengindikasikan bahwa pustakawan dalam mencapai prestasi kerjanya memiliki sikap menaati kewajiban dan menghindari larangan yang ditentukan dalam peraturan perundangundangan serta kemauan dan kemampuan pustakawan untuk bekerja sama dengan rekan sekerja, atasan, bawahan dalam unit kerjanya serta instansi lain dalam menyelesaikan suatu tugas dan tanggung jawab yang ditentukan, sehingga mencapai daya guna dan hasil guna yang sebesar-besarnya. Menurut Ayu (2015) Karyawan yang memiliki disiplin yang tinggi akan cenderung menyelesaikan pekerjaan tepat waktu sehingga dapat memenuhi target yang ditentukan perusahaan, dimana tercapainya target perusahaan ini merupakan indikator dari prestasi kerja karyawan.
Pengakuan terhadap pekerjaan ternyata memiliki pengaruh dengan orietasi pelayanan, integritas, komitmen, kedisiplinan dan kerjasama dengan koefisien rank spearman berturut-turut sebesar $0,419,0,568,0,546,0,832$, dan 0,701 pengakuan atas pekerjaan itu sendiri akan meningkatkan pelayanan yang prima bagi pustakawan. Peningkatan orientasi pelayanan tersebut juga akan muncul akibat adanya beberapa sikap yang mengikutinya yaitu mampu dipercaya, komitmen, disiplin serta kerja sama. Sehingga indikator tersebut sangat berhubungan nyata dengan bagaimana pustakawan bidang pertanian mendapatkan pengakuan terhadap pekerjaan yang mereka geluti.

Pekerjaan sebagai seorang pustakawan bidang pertanian membutuhkan orientasi terhadap pelayanan yang baik. Sehingga orientasi terhadap pelayanan memiliki hubungan dengan pekerjaan itu sendiri dengan koefisien rank sperman sebesar 0,511. rasa cinta terhadap pekerjaan pustakawan bidang pertanian menunjukkan orientasi pelayanan yang mereka lakukan akan optimal. Semakin pustakawan bidang pertanian mencintai pekerjaannya maka sikap dan perilaku kerja pustakawan bidang pertanian dalam memberikan pelayanan terbaik kepada yang dilayani antara lain meliputi masyarakat, atasan, rekan sekerja terwujud.

Penumbuhan rasa cinta terhadap pekerjaan itu sendiri memiliki hubungan dengan orientasi pelayanan yang akan dilakukan oleh pustakawan bidang pertanian. Sikap dan perilaku memberikan pelayanan terbaik oleh pustakawan bidang pertanian muncul karena mereka memiliki rasa cinta terhadap pekerjaannya. Pekerjaan tersebut dilakukan setiap harinya dan perilaku memberikan layanan terbaik terus mengalami perkembangan di level pustakawan Kementerian Pertanian. Kemampuan untuk bertindak sesuai dengan nilai, norma dan etika dalam organisasi juga muncul akibat adanya rasa cinta terhadap pekerjaan pustakawan termasuk pelayanan yang prima bagi pengunjung. Sehingga integritas memiliki hubungan dengan pekerjaan itu sendiri sebesar 0,303. kemampuan tersebut juga tidak jauh berbeda dengan integritas, komitmen, kedisiplinan dan kerjasama yang memiliki hubungan dengan rasa cinta terhadap pekerjaan itu seniri. Ditemukan bahwa rasa cinta pekerjaan yang dimiliki pustakawan sangat berhubungan dengan kemauan dan kemampuan untuk menyelaraskan sikap dan tindakan PNS untuk mewujudkan tujuan organisasi dengan mengutamakan kepentingan dinas daripada kepentingan diri sendiri, 
seseorang, dan/atau golongan. Kesanggupan Pegawai Negeri Sipil untuk menaati kewajiban dan menghindari larangan yang ditentukan dalam peraturan perundang-undangan dan/atau peraturan kedinasan yang apabila tidak ditaati atau dilanggar dijatuhi hukuman disiplin memacu mereka mencintai pekerjaanya. Kemauan dan kemampuan pustakawan bidang pertanian untuk bekerja sama dengan rekan sekerja, atasan, bawahan dalam unit kerjanya serta instansi lain dalam menyelesaikan suatu tugas dan tanggung jawab yang ditentukan, sehingga mencapai daya guna dan hasil guna yang sebesar-besarnya.

Tanggung jawab yang tinggi akan memotivasi pustakawan bidang pertanian untuk memiliki perilaku kerja yang baik. Berdasarkan hasil penelitian menunjukkan bahwa tanggung jawab berhubungan dengan orientasi pelayanan, integritas, komitmen, kedisiplinan, dan kerjasama. Orientasi pelayanan merupakan sikap dan perilaku kerja pustakawan bidang pertanian dalam memberikan pelayanan terbaik, sehingga tanggung jawab atas pekerjaan tersebut penting dilakukan. Ketika tanggung jawab telah muncul maka kemampuan untuk bertindak sesuai dengan nilai, norma dan etika dalam organisasi terwujud dengan adanya tanggung jawab yang tinggi. Tanggung jawab yang tinggi pustakawan bidang pertanian dilandasi dengan kemampuan mereka untuk memiliki komitmen terhadap pekerjaannya. Sehingga kesanggupan Pegawai Negeri Sipil untuk menaati kewajiban dan menghindari larangan yang ditentukan dalam peraturan perundang-undangan dan/atau peraturan kedinasan yang apabila tidak ditaati atau dilanggar dijatuhi hukuman disiplin juga diharapkan muncul. Tanggung jawab juga memiliki hubungan dengan kerja sama, kemauan dan kemampuan PNS untuk bekerja sama dengan rekan sekerja, atasan, bawahan dalam unit kerjanya serta instansi lain dalam menyelesaikan suatu tugas dan tanggung jawab yang ditentukan, sehingga mencapai daya guna dan hasil guna yang sebesar-besarnya. Menrut Khadafi (2010), Budaya kerja (kerjasama tim dan orientasi hasil) haruslah di jadikan nilai-nilai yang menjadi pedoman karyawan untuk membantu perusahaan meningkatkan kinerja karyawan dan tujuan perusahaan.

Pengelolaan perpustakaan yang baik akan meningkatkan orientasi pelayanan yang prima pula. Sehingga ditemukan bahwa kemajuan memiliki hubungan dengan orientasi pelayanan. Layanan prima yang dilakukan oleh pustakawan bidang pertanian dinilai berdasarkan pemberian pelayanan terbaik kepada yang dilayani antara lain meliputi masyarakat, atasan, rekan sekerja, unit kerja terkait, dan/atau instansi lain. Kemajuan pustakawan bidang pertanian dalam mengelola perpustakaan memiliki hubungan dengan integritas pustakawan. Penilaian meengenai kemampuan untuk bertindak sesuai dengan nilai, norma dan etika dalam organisasi diukur berdasarkan perilaku pustakawan bidang pertanian di pepustakaan. Integritas yang baik akan menjadi tolak ukur kemajuan seorang pustakawan. Kemajuan dan kemampuan untuk menyelaraskan sikap dan tindakan pustakawan untuk mewujudkan tujuan organisasi dengan mengutamakan kepentingan dinas. Disamping itu kedisiplinan dan kerjasama antar pustakawan bidang pertanian muncul karena mereka memiliki hasrat untuk maju.

Kebijakan instansi berhubungan dengan bagaimana orientasi pelayanan yang dilakukan oleh pustakawan bidang pertanian. Sikap dan perilaku kerja pustakawan bidang pertanian dalam memberikan pelayanan terbaik kepada yang dilayani merujuk kepada peraturan-peraturan yang diberikan oleh instansi kementerian pertanian. Lingkup Kementerian Pertanian memiliki delapan perpustakaan di seluruh Indonesia diantaranya perpustakaan. Puslitbangbun, Balittro, Balittri, Puslitbangtan, Puslitbanghorti, Balitklimat, BB. Pasca panen, BBSDLP, Balittanah, PSEKP, BP2TP, BALITVET, PUSTAKA, Puslitbangnak, Balitnak, BPATP, PPMKP, STTP Bogor, STTP Cinagara, BB. Padi, BPTP Jabar, BB. Pelatihan Pertanian, Sekba SDM, BPMSP Bekasi, Ditjennak dan Keswan, BKP, Dirjenbun, Biro Humas, BPSDMP, dan BPTP DKI. Kebijakan instansi akan menentukan kemana arah dari suatu instansi dan akan berhubungan dengan tingkat integritas pustakawan bidang pertanian. Pada penilitian ini di indikasikan bahwa kemampuan untuk bertindak sesuai dengan nilai, norma dan etika pustakawan bidang pertanian bercermin kepada kebijakan dan peraturan yang ada di perpustakaan tersebut. Pustakawan bidang pertanian dikatakan memiliki integritas tinggi ialah ketika mereka mampu untuk bertindak sesuai dengan arah instansi. Pada Kementerian Pertanian sendiri, penilaian perilaku integritas didasarkan oleh peraturan pemerintah nomor 46 Tahun 2011. Begitu pula halnya dengan komitmen pustakawan bidang pertanian akan tergantung dengan kebijakan yang ada di perpustakaan tersebut. Kemauan dan kemampuan untuk menyelaraskan sikap dan tindakan pustakawan bidang pertanian untuk mewujudkan tujuan organisasi secara disiplin dan berkemauan tinggi.

Pemenuhan terhadap apa yang dibutuhkan 
karyawan dalam menghadapi pekerjaan yang komplek berhubungan dengan bagaimana orientasi pelayanan yang diberikan pustakawan. Motivasi untuk memberikan pelayanan yang baik berhubungan dengan bagaimana kualitas atasan.

Berdasarkan hasil penelitian menyatakan bahwa kualitas atasan berhubungan dengan orientasi pelayanan. Diharapkan orientasi palayanan yang baik biasa di lakukan oleh keseluruhan pustakawan bidang pertanian.

Kondisi ini sesuai dengan penelitian yang dilakukan oleh Molatong et.al.,(2015) menyatakan bahwa gaya kepemimpinan kepala perpustakaan terhadap motivasi kerja pegawai sangatlah penting akan tetapi kepala perpustakaan belum maksimal karena sebagian pegawai kurang termotivasi dalam melaksanakan aktifitas di perpustakaan karena gaya kepemimpinan yang diterapkan cenderung gaya kepemimpinan otoriter sehingga menjadi penghambat dalam pelaksanaan di perpustakaan, dan pegawai yang memiliki kemampuan dalam mengolah perpustakaan hanyalah sebagian pegawai yang punya pemahaman yang lebih. Berdasarkan hal tersebut dapat disimpulkan bahwa gaya kepemimpinan yang tidak mengayomi akan merendahkan motivasi kerja untuk memberikan pelayanan yang baik.

Budiman (2015) menyatakan bahwa menjaga dan membangun hubungan yang baik antara atasan dan bawahan merupakan hal yang penting. Hubungan baik yang dibangun dengan komitmen bersama akan melahirkan perilaku kerja yang produktif dan menciptakan kesadaran akan nilai-nilai visi dan misi suatu organisasi. Perilaku kerja yang produktif dan menciptakan nilai-nilai tersebut merupkan fungsi dari kedisiplinan dan integritas. Selaras dengan penelitian ini yang menyatakan bahwa adanya hubungan antara integritas dan disiplin terhadap kualitas atasan. Begitu juga penelitian yang dilakukan oleh Yulianti (2015) yang menyatakan bahwa kepemimpinan berpengaruh positif dan signifikan terhadap peningkatan kinerja SDM artinya kinerja SDM yang dibangun oleh kemampuan atasan memberikan pengaruh yang ideal dan motivasi inspirasional.

Integritas, komitmen, kedisiplinan dan kerja sama merupakan hal yang terbentuk akibat adanya hubungan interpersonal dengan pengguna perpustakaan. Pengguna perpustakaan dalam hal ini adalah orang-orang yang melakukan komunikasi dengan pustakawan. Kemampuan untuk bertindak sesuai dengan nilai, norma dan etika dalam organisasi pustakawandapattercermindaribagimanapustakawan melakukan komunikasi dengan lingkungannya. Begitu pula dengan kerja sama yang diartikan sebagai kemauan dan kemampuan PNS untuk bekerja sama dengan rekan sekerja, atasan, bawahan dalam unit kerjanya serta instansi lain dalam menyelesaikan suatu tugas dan tanggung jawab yang ditentukan, sehingga mencapai daya guna dan hasil guna yang sebesar-besarnya, kondisi ini menunjukkan bahwa sangat penting adanya komunikasi interpersonal agar kerjasama bias terwujud.

Kondisi kerja memiliki hubungan dengan orientasi pelayanan, integritas, komitmen, kedisiplinan dan kerjasama. Adapun hasil penelitian menunjukkan besarnya koefisien korelasi Rank Spearman berturut-turut sebesar 0,502, 0,505, 0,363, 0,786 , dan 1,000 . Kondisi kerja yang nyaman akan menciptakan motivasi sendri bagi pustakawan. Kondisi eksternal dari luar diri pustakawan bidang pertanian ialah kondisi kerja paling kondusif bagi pustakawan.

Orientasi pelayanan akan baik bila kondisi kerja yang tercipta juga baik. Motivasi pustakawan bidang pertanian memberikan pelayanan sebaikbaiknya di dukung dengan kodisi lingkungan kerja yang mendukung pula. Salutondok (2015) mengemukakan hal yang berbeda dimana kondisi kerja berpengaruh dan tidak signifikan terhadap kinerja pegawai. Kinerja pegawai tidak dipengaruhi oleh kondisi lingkungan kerjanya. Bertolak belakang dengan penelitian ini yang menyatakan bahwa kinerja pelayanan akibat lingkungan kerja yang nyaman. Integritas yang merupakan kemampuan untuk bertindak sesuai dengan nilai, norma dan etika dalam organisasi juga akan berhubungan dengan kondisi kerja yang baik. Pustakawan bidang pertanian menyatakan bahwa kemampuan mereka bertindak sesuai aturan apabila kondisi kerja yang baik mereka dapatkan dan lebih mudah untuk memahami aturan. Sehingga terciptanya sikap disiplin bagi pustakawan bidang pertanian.

Disiplin diperlukan penilaian kinerja seorang pustakawan bidang pertanian. Hal ini sesuai dengan penelitian Salutondok (2015) yang menyatakan bahwa disiplin berpengaruh terhadap kinerja karyawan. Bagitu pula dengan kerja sama, kemauan dan kemampuan pustakawan untuk bekerja sama dengan rekan sekerja, atasan, bawahan dalam unit kerjanya serta instansi lain dalam menyelesaikan suatu tugas dan tanggung jawab yang ditentukan sangat tergantung dengan kondisi kerja yang mereka alami. 
Uji Beda Motivasi Kerja Pustakawan Bidang Pertanian Ahli dan Terampil

Motivasi kerja ditinjau dari faktor intrisik tidak memiliki perbedaan nyata berdasarkan uji t-test. Uji t-test pada faktor intrinsik tidak terdapat perbedaan nyata pada setiap indikatornya. Indikator prestasi memiliki signifikasi sebesar 0,982 yang berada diatas nilai signifikasi 0,05 sehingga tidak signifikan pada taraf tersebut. Begitu juga dengan pengakuan, pekerjaan itu sendiri, tanggung jawab dan kemajuan memilki sigifikasi berturut-turut sebesar $0,310,0,203,0,542$, dan 0,248 . Nilai tersebut juga berada diatas 0,05 yang memiliki arti tidak signifikan dan tidak memiliki perbedaan nyata. Berbeda dengan faktor intrinsik, hanya indikator kualitas atasan merupakan satu-satu nya indikator yang memiliki perbedaan nyata antara pustakawan bidang pertanian ahli dan terampil dengan signifikasi sebesar 0,047.

Kualitas atasan memiliki perbedaan nyata dengan signifikasi sebesar 0,047. Atasan sebagai salah satu orang memiliki kuasa atas tugas dan wewenang tertentu dan memberikan perintah kepada bawahannya sesuai dengan pekerjaannya masing-masing. Menurut Senyah (2003) dalam penelitiannya menemukan bahwa atasan pustakawan yang bersahabat ialah $75 \%$. Hal ini mengindikasikan bahwa sikap atasan sangat menentukan derajat motivasi kerja responden. Sebagiaan besar pustakawan bidang pertanian ahli setuju bahwa kualitas atasan akan memotivasi kinerja mereka. Penilian terhadap atasan yang berkualitas akan semakin memotivasi mereka. Bagi pustakawan bidang pertanian ahli yang memiliki pendidikan dan pengalaman yang tinggi, penting bagi mereka untuk menilai mutu dari atasan mereka. Atasan merupakan orang yang memimpin, mampu memiliki kualitas pendidikan yang baik (berasal dari pustakawan ahli), mengayomi dan membuat berkembang sehingga kondisi tersebut menjadikan kenyamanan kerja bagi pustakawan ahli. Selain itu tingkat kualitas bagi pustakawan bidang pertanian lebih dinilai secara intelektual, sehingga ada rasa kepercayaan yang tinggi terhadap kemampuan atasan yang memiliki dan lebih menghormati atasan yang pendidikannya minimal setara dengan mereka. Apabila atasan memiliki kemampuan yang setara dengan terampil, rasa kepercayaan pustakawan ahli akan menurun. Sementara pustakawan bidang pertanian terampil menilai kualitas atasan berdasarkan kapabilitas kepemimpinannya dan mampu mengayomi mereka dalam melakukan pekerjaan.

\section{Kesimpulan}

Hasil penelitian menunjukkan bahwa jenis kelamin berhubungan dengan kebijakan instansi, dan tingkat pendidikan non formal berhubungan dengan kebijakan instansi serta gaji/tunjangan. Selanjutnya pendidikan berhubungan dengan kebijakan

Tabel 8. Nilai Uji Beda Motivasi Kerja pada Pustakawan Bidang Pertanian Ahli dan Terampil

\begin{tabular}{lcccl}
\hline \multirow{2}{*}{\multicolumn{1}{c}{ Motivasi }} & \multicolumn{2}{c}{ Rataan } & Sig & Keterangan \\
\cline { 2 - 3 } & $\begin{array}{c}\text { Ahli } \\
\mathbf{N = 4 2}\end{array}$ & $\begin{array}{c}\text { Terampil } \\
\mathbf{N = 3 0}\end{array}$ & $\begin{array}{c}\text { Sig } \\
\text { (2-tailed) }\end{array}$ & \\
\hline Intrinsik & 2,738 & 0,989 & 0,982 & Tidak terdapat perbedaan nyata \\
Prestasi & 3,238 & 0,983 & 0,310 & Tidak terdapat perbedaan nyata \\
Pengakuan & 3,048 & 0,987 & 0,203 & Tidak terdapat perbedaan nyata \\
Pekerjaan itu sendiri & 2,333 & 0,902 & 0,542 & Tidak terdapat perbedaan nyata \\
Taggung Jawab & 3,119 & 0,328 & 0,248 & Tidak terdapat perbedaan nyata \\
Kemajuan & & & & \\
Ekstrinsik & 3,119 & 0,328 & 0,248 & Tidak terdapat perbedaan nyata \\
Kebijakan instansi & 3,214 & 0,415 & 0,047 & Terdapat perbedaan nyata \\
Kualitas atasan & 3,357 & 0,485 & 0,231 & Tidak terdapat perbedaan nyata \\
Hubungan interpersonal & 3.167 & 0.490 & 0.408 & Tidak terdapat perbedaan nyata \\
Kondisi kerja & 3.167 & 0.537 & 0.243 & Tidak terdapat perbedaan nyata \\
Gaji Tunjangan & & &
\end{tabular}

Keterangan : Signifikan $(2$-tailed $)<0.05=$ signifikan 
instansi, pengelolaan perpustakaan berhubungan dengan prestasi; pengakuan; pekerjaan itu sendiri; kemajuan; hubungan interpersonal; gaji/tunjangan. Serta pelayanan perpustakaan berhubungan dengan hubungan interpersonal dan gaji/tunjangan, dilihat dari perbedaan motivasi kerja pustakawan bidang pertanian ahli dan terampil, hanya kualitas atasan yang memiliki perbedaan antara pustakawan bidang pertanian ahli dan terampil.

\section{Daftar Pustaka}

Ayu J. 2015. Pengaruh Disiplin Kerja dan Motivasi Kerja terhadap Prestasi Kerja Karyawan (Studi Pada PT BPR Gunung Ringgit Malang). JAB, 25(1) : $1-9$

Bachtiar D. 2012. Pengaruh Motivasi dan Lingkungan Kerja terhadap Kinerja Karyawan. Management Analysis Journal, 1(1) : 1-6

Budiman. 2015. Pengaruh Kualitas Hubungan antara Atasan - Bawahan terhadap Perilaku Kerja Kontra Produktif Studi pada Perawat Rumah Sakit Khusus Mata. Jurnal Psikologi Islami, 1(2) :35-41.

Brahmasari A, Suprayetno A. 2008. Pengaruh Motivasi Kerja, Kepemimpinan dan Budaya Organisasi terhadap Kepuasan Kerja Karyawan serta Dampaknya pada Kinerja Perusahaan (Studi kasus pada PT. Pei Hai International Wiratama Indonesia). Jurnal Manajemen Dan Kewirausahaan. 10(2) : 124-135.

Danim S. 2004. Motivasi Kepemimpinan dan Efektivitas Kelompok. Jakarta (ID): Rineka Cipta.

Desak Putu Parmiti. 2006. Hubungan Motivasi Kerja Dan Kepuasan Kerja dengan Kinerja Pustakawan pada Perpustakaan Instansi Pemerintah di Kabupaten Buleleng Provinsi Bali. Jurnal Pendidikan dan Pengajaran IKIP Negeri Singaraja, 2(39) : 311-325.

Erni NY. 2015. Kepuasan Kerja dan Kinerja Dinas Pendapatan dan Kekayaan Aceh. [Tesis]. Aceh (ID): Universitas Syah Kuala.

Gatot S. 2009. Automasi Perpustakaan. Malang (ID): Universitas Negeri Malang Press.

Hasibuan M. 2012. Manajemen Sumber Daya Manusia. Jakarta (ID): Bumi Aksara.

Hermawati A. 2012. Pengaruh Motivasi dan Kemampuan terhadap Prestasi Kerja Pegawai Dinas Pendidikan Pemerintah Kota Batu. Jurnal Dinamika Dotcom, 3(2) : 29-41
Irham F. 2016. Pengantar Manajemen Sumber Daya Manusia Konsep \& Kinerja. Edisi Pertama. Jakarta (ID): Mitra Wacana Media.

Jaya I. 2012. Pengaruh Kemampuan dan Motivasi Kerja terhadap Kinerja Pegawai Dinas Pendidikan Kabupaten Tanjung Jabung Barat. Jurnal Penelitian Universitas Jambi Seri Humaniora, 14(1) : 37-46.

Khadafi M. 2010. Pentingnya Kerjasama Tim dan Orientasi Hasil terhadap Kinerja Karyawan. Jurnal Eksis, 6(2) : 1440-1605.

Makarim, Luthfiati. 2006. Pustakawan Idaman Pemakainya: Sebuah Studi Di Perpustakaan Nasional RI. Media Pustakawan: Media Komunikasi antar Pustakawan, 13(3\&4) : $11-18$ Mamik. 2010. Organisasi dan Manajemen Pelayanan Kesehatan dan Kebidanan. Surabaya (ID): Prins Media.

Mangkunegara AP. 2014. Manajemen Sumber Daya Manusia Perusahaan. Jakarta (ID): PT Rajagrafindo Persada.

Marihot. 2009. Manajemen Sumber Daya manusia, Pengadaan, Pengembangan Pengkompensasian, Peningkatan Produktivitas Pegawai. Jakarta (ID): Grafindo.

Molatong C, Bohan A, Golung AM. 2015. Gaya Kepemimpinan Kepala Perpustakaan terhadap Motivasi Kerja Pegawai di Perpustakaan Arsip dan Dokumentasi Kota Kotamobagu. E-journal "Acta Diurna". 4(3) : 1-11.

Mitchell T. 1998. Empowering People: Pemberdayaan Sumberdaya Manusia. Terjemahan. Yogyakarta (ID): Penerbit Kanisius.

Rachmawati F. 2013. Pengaruh Pelatihan Kerja dan Motivasi Kerja terhadap Kinerja Karyawan pada PT Trias Sentosa, Krian Sidoarjo. Agora, 4(2) : 259-263

Riyadi S. 2011. Pengaruh Kompensasi Finansial, Gaya Kepemimpinan, dan Motivasi Kerja terhadap Kinerja Karyawan pada Perusahaan Manufaktur di Jawa Timur. Jurnal Manajemen Dan Kewirausahaan, 13( 1) : 40-45,

Robbins PS. 1998. Organization Behavior: Concept, Controversies,Applications. New Jersey (US): Prentice-Hall Inc.

Robbins SP. 2002.Prinsip-Prinsip Perilaku Organisasi. Edisi kelima. Jakarta (ID): Erlangga.

Senyah Y. 2003. Motivation and Productivity in Academic Libraries: "A Case Study of the Kwame Nkrumah University of Science and 
Technology Library, Kumasi”, Journal of Science and Technology, 23(2) : 80-89.

Salutondok Y, Supandi AS. 2015. Pengaruh Kepemimpinan, Motivasi, Kondisi Kerja dan Disiplin terhadap Kinerja Pegawai Di Kantor Sekretariat DPRD Kota Sorong. Jurnal EMBA. 3(3) : 849-862.

Sidanti H. 2015. Pengaruh Lingkungan Kerja, Disiplin Kerja dan Motivasi Kerja terhadap Kinerja Pegawai Negeri Sipil di Sekretariat DPRD Kabupaten Madiun. Jurnal JIBEKA, 9(1) : $44-53$.

Sri AH. 2006. Analisis Faktor-Faktor yang Menjadi Prediktor Organisasi Pembelajaran untuk Meningkatkan Kinerja Karyawan (Study Kasus Pada PT. Gramedia Pustaka Utama Jakarta). Semarang (ID): Universitas Diponegoro.

Sumbangsih N, Nelisa M. 2013. Pengaruh Pemberian Insentif terhadap Motivasi Kerja Pustakawan di Perpustakaan Universitas Bung Hatta Padang. Jurnal Ilmu Informasi Perpustakaan dan Kearsipan, 2(1) : 178-185.

Suwatno, Donni. 2011. Manajemen SDM: dalam organisasi publik dan bisnis. Bandung (ID): Alfabeta.

Winarni. 2013. Pengaruh Gaji terhadap Kinerja Pegawai Kantor Perpustakaan dan Arsip Kota Salatiga Melalui Variabel Motivasi Kerja Sebagai Variabel Intervening. Among Makarti, 6(11) : 4871.

Wirawan. 2009. Evaluasi Kinerja Sumber Daya Manusia : Teori, Aplikasi, dan Penelitian. Jakarta (ID): Salemba Empat.

Wahid Nashihuddin, Dwi Ridho Aulianto. 2015. Strategi Peningkatan Kompetensi dan Profesionalisme Pustakawan di Perpustakaan Khusus. Jurnal Perpustakaan Pertanian, 24(2) : 51-58.

Yulianti, Wuryanti. 2015. Pengaruh Kepemipinan Transformasional, Integritas Perilaku dan Kepercayaan terhadap Pimpinan Dalam Peningkatan Kinerja Sdm. CBAM, 2(1) : 282300. 